Article

\title{
The Impact of Energy Consumption and Economic Growth on Carbon Dioxide Emissions
}

\author{
Oluyomi A. Osobajo ${ }^{1, * \mathbb{C}}$, Afolabi Otitoju ${ }^{2}$, Martha Ajibola Otitoju ${ }^{3}$ and Adekunle Oke ${ }^{1(D)}$ \\ 1 Aberdeen Business School, The Robert Gordon University, Garthdee Road, Aberdeen AB10 7QE, UK; \\ a.oke1@rgu.ac.uk \\ 2 Renewable Energy Consultant, Trinomial Solutions Ltd., Aberdeen AB12 3DZ, UK; \\ afolabiotitoju@yahoo.com \\ 3 Repsol Sinopec Resources UK Limited, Holburn Road, Aberdeen AB10 6BZ, UK; ainalonge@yahoo.com \\ * Correspondence: o.osobajo@rgu.ac.uk
}

Received: 29 July 2020; Accepted: 17 September 2020; Published: 25 September 2020

\begin{abstract}
This study explored the effect of energy consumption and economic growth on $\mathrm{CO}_{2}$ emissions. The relationship between energy consumption, economic growth and $\mathrm{CO}_{2}$ emissions was assessed using regression analysis (the pooled OLS regression and fixed effects methods), Granger causality and panel cointegration tests. Data from 70 countries between 1994-2013 were analysed. The result of the Granger causality tests revealed that the study variables (population, capital stock and economic growth) have a bi-directional causal relationship with $\mathrm{CO}_{2}$ emissions, while energy consumption has a uni-directional relationship. Likewise, the outcome of the cointegration tests established that a long-run relationship exists among the study variables (energy consumption and economic growth) with $\mathrm{CO}_{2}$ emissions. However, the pooled OLS and fixed methods both showed that energy consumption and economic growth have a significant positive impact on $\mathrm{CO}_{2}$ emissions. Hence, this study supports the need for a global transition to a low carbon economy primarily through climate finance, which refers to local, national, or transnational financing, that may be drawn from public, private and alternative sources of financing. This will help foster large-scale investments in clean energy, that are required to significantly reduce $\mathrm{CO}_{2}$ emissions.
\end{abstract}

Keywords: climate change; climate finance; economic growth; $\mathrm{CO}_{2}$ emissions; energy consumption

\section{Introduction}

Environmental issues have taken leading discussions in our contemporary times in both developing and developed economies due to environmental deterioration. This further raises concerns about climate change and global warming, which arises mainly from the emission of greenhouse gases [1]. These changes are often linked to natural causes (i.e., continental drifts, volcanic activities, solar radiation and ocean currents) and direct and indirect human activities, which affect the global atmospheric composition and variability of the natural climate. However, scholars have argued that the increase in human activities due to the emergence of industrialization, the increase in the growth of the global population and the need to meet up with such transformations are the main causes of climate change [2,3]. Also, human activities such as deforestation for agricultural and commercial purposes, burning of fossil fuel and changes in the use of land due to population growth are contributing significantly to a surge in greenhouse gas emissions. Despite the contribution of industrialization in promoting economic growth by increasing the amount of goods and services produced, shaping lives and making the society a better place, it left us with an issue of increasing greenhouse emissions.

In today's world, the demand for energy due to the growing population and urbanization is on the increase [4]. This is essential to keep pace with the rapid disruptions and transformation in 
global economies. Energy is pivotal to human lives and to the social, economic and environmental development of the global economy. It is likely impossible to produce, deliver, or use mainstream commodities without consuming energy. Hence, Yildirim [5] observed that insufficient energy would negatively impact the performance of different sectors of the economy such as transport and a country's social life. However, the increase in the consumption of energy is becoming a threat to the global ecosystem. This has given rise to more prolonged droughts, rising sea levels and the rising occurrence of heatwaves, which are of grave negative impacts on the environment. Although there is an awareness about the consequences of human activities, Urry [3] observed that there is a rise in the emission level of greenhouse gases such as Carbon dioxide $\left(\mathrm{CO}_{2}\right)$ into the atmosphere.

Likewise, the need for economic growth has led to environmental degradation, which is often a resultant effect of development and industrialization in both developing and developed countries. The economic growth of any country is dependent on different factors, which may impose negative impacts on the environment such as unsustainable natural resource exploitation, environmental pollution and climate change [6]. Also, the rapid increase in urbanization in many countries has fast-tracked economic growth with the resultant effect of an increase in energy consumption. Hence, the key issue that many countries are facing is the level of carbon dioxide in the environment that is increasing significantly due to energy consumption and economic growth. According to Kasman and Dunman [7], a majority of the energy originates from fossil fuels such as coal and natural oil and gas, which also has resulted in the increase of $\mathrm{CO}_{2}$ emissions level. This has further prompted scholars to argue that $\mathrm{CO}_{2}$ emission is invisible, and its effect may take years to materialise [8].

Although several factors such as population size, the carbon intensity of energy, economic growth, clean nuclear energy use, fossil energy consumption, renewable energy, urbanization and other air pollutants (PM10, PM2.5, SO2, NO2, CO, $\mathrm{B}(\mathrm{a}) \mathrm{P}$ ) $[9,10]$ have been identified to be responsible for the growth in the global $\mathrm{CO}_{2}$ emissions level, the aim of this study is to explain the impact of energy consumption and economic growth on $\mathrm{CO}_{2}$ emissions. Given the rapid global economic growth resulting in increased energy consumption, understanding the relationship between these variables is essential to ensure a balance between energy consumption, economic growth and $\mathrm{CO}_{2}$ emissions. Also, it will help direct focus on addressing the threats (i.e., preventing a $40^{\circ} \mathrm{C}$ world) posed by the changes in global climate.

\section{Literature Review}

\subsection{Overview of Greenhouse Gas Emissions}

Greenhouse gases have been categorised as atmospheric gaseous constituents, both anthropogenic and natural. These constituents are known to imbibe and emit radiation at certain wavelengths within the spectrum of infrared radiation emitted by the clouds, atmosphere and the surface of the Earth. Hossain [11] and Paiva et al. [12] asserted that greenhouse gases remain a significant cause of climate change and global warming. This is consistent with Resnik's [13] argument that the adverse effects of climate change due to greenhouse gases on human health, the environment and society are profuse. Hence, Meltzer [14] concluded that over 150,000 deaths per year are attributed to the resultant effects of environmental pollution. Although there are many greenhouse gases, $\mathrm{CO}_{2}$ is attracting more recognition due to its persistence in the atmosphere and for its use as a baseline for estimating the global warming potential (GWP) of other greenhouse gases [15-17]. Rahman [18] added that between 1990 to 2013, the greenhouse gas concentration has increased by $34 \%$ with over $80 \%$ of this figure being a resultant effect of $\mathrm{CO}_{2}$ emissions. This is in line with Amri's [19] assertion that $\mathrm{CO}_{2}$ emissions have increased significantly from 67 million metric tons to 134 million metric tons. Considering that the rising $\mathrm{CO}_{2}$ emission level remains a global concern $[18,20]$, it is crucial to explore the drivers of $\mathrm{CO}_{2}$ emissions [21,22]. Based on previous studies (Table 1), one could conclude that energy consumption and economic growth are the two most mentioned drivers of $\mathrm{CO}_{2}$ emissions. 
Table 1. Drivers of $\mathrm{CO}_{2}$ emissions (summarised from the literature).

\begin{tabular}{cr}
\hline Authors & CO $_{2}$ Emissions Drivers \\
\hline Stolyarova [23] & GDP and energy consumption. \\
\hline Sharma [24] & Per capita GDP and urbanization. \\
\hline Cetin and Ecevit [25] & Energy consumption and urbanization. \\
\hline Keho [26] & The share of industrial sector in GDP, per capita income and trade openness. \\
\hline Zakarya et al. (2015) [27] & GDP, energy consumption and Foreign direct investments. \\
\hline Ab-Rahim and Xin-Di [28] & Energy consumption, trade openness and economic growth. \\
\hline Jiang and Guan [29] & GDP per capita, population, carbon intensity of energy and GDP energy intensity. \\
\hline Jiang et al. [30] & Social consumption and consumption behaviour. \\
\hline Talbi [9] & Economic growth, population size, fossil energy consumption, clean nuclear \\
energy use, renewable energy and waste energy conversion.
\end{tabular}

\subsection{The Nexus of Energy Consumption, Economic Growth and $\mathrm{CO}_{2}$}

In recent times, several studies have focused on understanding the link between energy consumption, economic growth and $\mathrm{CO}_{2}$ emissions [5]. Nevertheless, the relationship that exists between these variables has been explained in different ways $[18,20]$. Table 2 present a synopsis of preceding empirical studies implemented to explain the link between energy consumption, economic growth and $\mathrm{CO}_{2}$ emissions.

Table 2. Synopsis of preceding empirical studies on the relationship between energy consumption, economic growth and $\mathrm{CO}_{2}$ emissions (authors generated).

\begin{tabular}{|c|c|c|c|c|}
\hline Author & Time & Method & Country & Results \\
\hline $\begin{array}{l}\text { Abdallah and } \\
\text { Abugamos [31] }\end{array}$ & 1990-2014 & $\begin{array}{l}\text { Parametric and } \\
\text { semi-parametric panel fixed } \\
\text { effects models }\end{array}$ & $\begin{array}{l}\text { MENA } \\
\text { Countries }\end{array}$ & $\begin{array}{l}\text { There exists an inverted u-shaped relationship between } \mathrm{CO}_{2} \text { emissions } \\
\text { and urbanisation. However, there is a significant relationship between } \\
\text { GDP and EC with respect to } \mathrm{CO}_{2} \text { emissions. The population shows a } \\
\text { positive impact, but only significant at } 5 \% \text { using a semi-parametric } \\
\text { model. }\end{array}$ \\
\hline $\begin{array}{l}\text { Mizra and } \\
\text { Kanwal [32] }\end{array}$ & 1971-2009 & $\begin{array}{l}\text { Error correction model and } \\
\text { Johansen-Juselius } \\
\text { Cointegration }\end{array}$ & Pakistan & $\begin{array}{l}\text { A bidirectional causality relationship exists between } \mathrm{EC} \text { and } \mathrm{GDP}, \mathrm{CO}_{2} \\
\text { and } \mathrm{GDP}, \mathrm{CO}_{2} \text { and } \mathrm{EC} \text {, in both the short and long run. }\end{array}$ \\
\hline $\begin{array}{l}\text { Rehman and } \\
\text { Rashid [34] }\end{array}$ & 1960-2015 & $\begin{array}{l}\text { Johansen Fisher and Pedroni } \\
\text { cointegration, FMOLS and } \\
\text { DLOS }\end{array}$ & $\begin{array}{l}\text { SAARC } \\
\text { Countries }\end{array}$ & $\begin{array}{l}\text { There exists a relationship between GDP, energy consumption and } \mathrm{CO}_{2} \\
\text { emissions. Also, there exists an inverted U-shaped relationship } \\
\text { between GDP and } \mathrm{CO}_{2} \text { emissions. }\end{array}$ \\
\hline $\begin{array}{l}\text { Esso and Keho } \\
\text { [17] }\end{array}$ & $1971-2010$ & Bounds Testing & $\begin{array}{l}\text { Sub-Saharan } \\
\text { Countries }\end{array}$ & $\begin{array}{c}\text { A long-run causality relationship exists between GDP and } \mathrm{EC} \text { and } \mathrm{CO}_{2} \\
\text { emissions. However, a short-run causality relationship exists between } \\
\text { the variables for Ghana, the Democratic Republic of Congo, Benin, } \\
\text { Nigeria and Senegal. }\end{array}$ \\
\hline $\begin{array}{l}\text { Kasman and } \\
\text { Dunman [7] }\end{array}$ & 1992-2010 & $\begin{array}{l}\text { FMOLS and Granger } \\
\text { causality }\end{array}$ & $\begin{array}{l}\text { EU member } \\
\text { and candidate } \\
\text { countries }\end{array}$ & $\begin{array}{l}\text { There exists a long-run relationship between energy consumption, GDP, } \\
\mathrm{CO}_{2} \text { emissions, urban population and trade openness. Likewise, there } \\
\text { exists an inverted U-shaped relationship between } \mathrm{CO}_{2} \text { emissions and } \\
\text { real income. }\end{array}$ \\
\hline $\begin{array}{l}\text { Saidi and } \\
\text { Hammami [20] }\end{array}$ & 1990-2012 & $\begin{array}{l}\text { Generalised method of } \\
\text { moments }\end{array}$ & 58 countries & $\begin{array}{l}\mathrm{CO}_{2} \text { has a significant positive impact on energy consumption. Likewise, } \\
\text { economic growth has a positive impact on energy consumption. }\end{array}$ \\
\hline $\begin{array}{l}\text { Dritsaki and } \\
\text { Dritsaki [36] }\end{array}$ & 1960-2009 & ECM and FMOLS DOLS & $\begin{array}{l}\text { Greece, } \\
\text { Portugal and } \\
\text { Spain. }\end{array}$ & $\begin{array}{l}\text { There exists a long-run relationship between energy consumption, GDP } \\
\text { and } \mathrm{CO}_{2} \text { emissions. Likewise, positive and significant relationships } \\
\text { exist between } \mathrm{EC} \text { and } \mathrm{CO}_{2} \text { emissions and between GDP and energy } \\
\text { consumption for Greece and Spain at a } 1 \% \text { significance level and at a } \\
10 \% \text { significance level for Portugal. }\end{array}$ \\
\hline
\end{tabular}


Table 2. Cont.

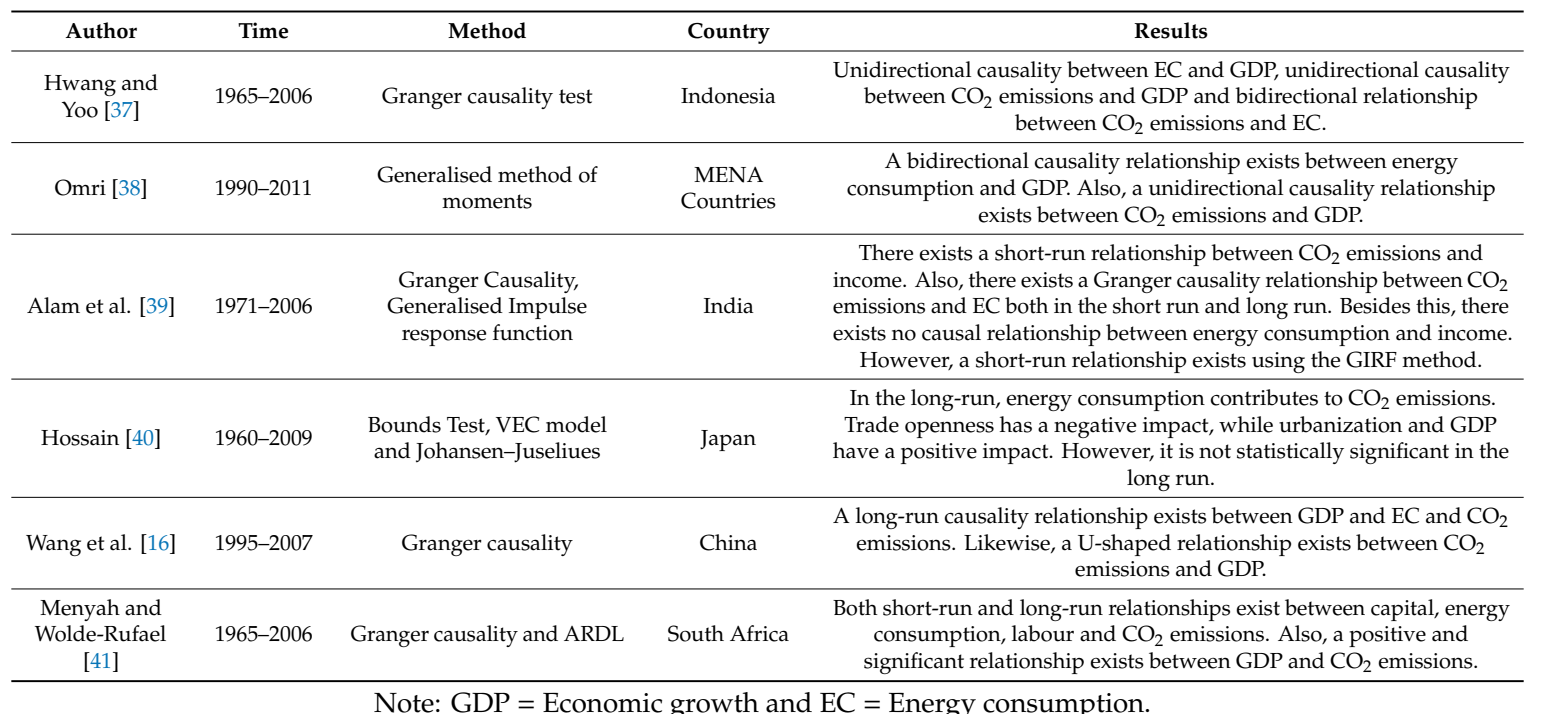

As evident from these studies, scholars have focused on different periods and countries, while using different energy usage proxy variables. This has given rise to some inconsistencies in the findings and results across these studies [35,42]. Hence, the different studies analysed suggest that there is a need to take policy-related actions to address these outcomes [11,17]. It is, therefore, not surprising that efforts are being made at the global scene to further prevent the effects of $\mathrm{CO}_{2}$ emissions by fostering a low carbon economy [1,43].

\subsection{The Role of Climate Finance in the Transition to a Low Carbon Economy}

Organisations such as the United Nations (UN) and the Intergovernmental Panel on Climate Change (IPCC) have taken different actions and measures in addressing climate change issues [3]. Worth mentioning is the 13th Conference of Parties (COP) held in 2007 at Bali in which the stakeholders presented finance as a pivotal factor to address climate change issues [44]. Thus, the emergence of the concept of "climate finance". Even though the concept lacks a generally accepted definition, it is perceived as the resources invested in climate change mitigation and adaptation measures [44,45]. The 2009 COP held in Copenhagen further affirmed the importance of climate finance in combating global climate change. This led to the generation of over $\$ 30$ billion in aid between the period of 2010 to 2012 from developed countries to developing economies [14]. Also, an additional mobilization for $\$ 100$ billion a year by 2020 was proposed by developed economies to developing economies. This is scheduled to extend until 2025. This is in line with the argument by Steckel et al. [46] that even though most of the $\mathrm{CO}_{2}$ emissions come from developed countries due to industrialization, it is essential to involve both the developing and emerging economies in the fight against the reduction of global emissions.

\section{Materials and Methods}

The aim of this study was to explore the impact of energy consumption and economic growth on $\mathrm{CO}_{2}$ emissions. As a result, quantitative data for this study was sourced from the World Bank (World development indicators), a reliable and credible database. It is the primary World Bank collection of development indicators, compiled from officially recognised international sources. In addition, it presents the most accurate and current global development data available and includes national, regional and global estimates. The data was analysed and examined quantitatively using Granger causality to fulfil the study aim and allowed for conclusive and reliable findings [36,47]. 


\section{Definition of Variables and Model}

To achieve the study aim, the dependent variable is $\mathrm{CO}_{2}$ emissions (assumed to be caused or influenced by other factors), while energy consumption, economic growth, population and capital stock are independent variables [48,49] as shown in Table 3.

Table 3. Dependent and independent variable synopsis.

\begin{tabular}{ccc}
\hline Name & Description & Eviews Code \\
\hline $\mathrm{CO}_{2}$ emissions & $\mathrm{CO}_{2}$ emissions in kilo tonne $(\mathrm{kt})$ & $\mathrm{CO}_{2}$ \\
\hline Energy consumption & Energy use (kg of oil equivalent per capita) & ENRGY_CONSC \\
\hline Economic growth & GDP growth (annual \%) & GDP \\
\hline Population & Population total & POP \\
\hline Capital stock & Gross fixed capital formation (constant 2010 US\$) & CAP_FORM \\
\hline
\end{tabular}

The independent variables are briefly defined below:

GDP growth (\% annual): It measures a country's economic performance, which is determined by its annual percentage growth from one year to the next. There has been an increase in $\mathrm{CO}_{2}$ emissions due to the persistent rise in land clearance and energy use resulting from growth through urbanization and industrialization. Hence, we expect a positive relationship between the variables. This variable has also been used in previous literature $[5,50]$.

Energy consumption: It measures the energy use that is obtained through fossil fuel from oil and coal. The unit of measurement for energy use was taken to be $\mathrm{kg}$ of oil equivalent per capita, which measures energy consumption per head of the population of a country. Due to the increase in energy consumption, the $\mathrm{CO}_{2}$ emission level is expected to increase also. Thus, we expect a positive relationship. This variable has been included in studies conducted by Esso [17] and Saidi and Hammami [20].

Capital Stock: To measure capital stock, this study employed the Gross fixed capital formation (constant 2010 US dollar), which is essential to any country's economic growth. This study expects a positive relationship because an increase in capital stock will result in an increase in $\mathrm{CO}_{2}$ emissions [38,47].

Population: This variable accounts for the total number of people living in a country at a point in time. A rise in a country's population will give rise to an increase in deforestation, land clearances for commercial and/or agriculture purposes and energy use (fossil fuel). These actions significantly add to global $\mathrm{CO}_{2}$ emissions. Hence, we do expect a positive relationship between the variables [34,51].

To test the effects of the independent variables on the dependent variable, longitudinal data [52] that covered a 20 year period, between 1994 and 2013 for 70 countries (Table 4) was collected from the World Bank database. This avails the authors of the opportunity to establish changes that may have occurred over the time horizon covered.

Table 4. List of countries considered for the study.

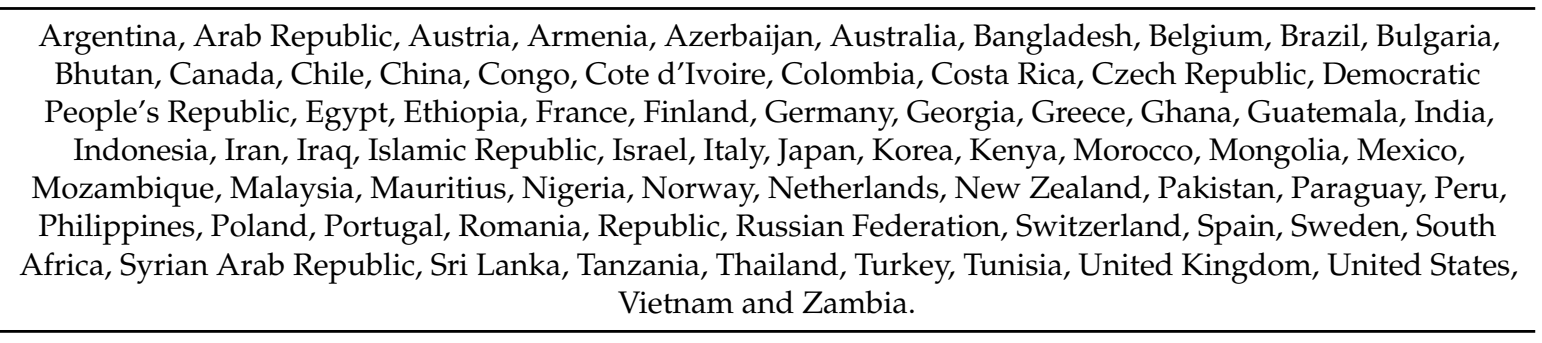

Using a four-step process, the gathered data was analysed using Granger causality, cointegration tests and a linear regression model. The first step ascertained the stationarity and order of integration 
among the study variables using the unit root test. In the second step, the long-run relationship between the study variables was examined using the cointegration tests. The third analysed the causal relationship between the study variables using the Granger causality test. The fourth involved investigating the effect of the independent study variables on $\mathrm{CO}_{2}$ emissions using the regression analysis method. The regression model is therefore as stated below:

$$
\text { yit }=\beta 0+\beta 1 x i t+\beta 2 x i t \ldots \ldots \beta n x i t+d t+a i+u i t
$$

where:

$\mathrm{y}=$ Dependent variable

$\mathrm{x}=$ Independent variable

$\beta 0=$ Constant

$\beta 1, \beta 2, \beta n=$ Coefficient of $x 1, x 2$ and $x n$ respectively.

$\mathrm{dt}=$ dummy variable

uit $=$ error term

ai $=$ unobserved heterogeneity

$\mathrm{t}=$ Time

$\mathrm{i}=$ Country.

It is worth stating that this study did not include dummy variables. This is because behaviour is assumed not to vary over time. Also, the study employed the fixed effects model alongside the pooled OLS to address unobserved heterogeneity concerns.

Hence, the regression model is rewritten as:

$$
\left(\mathrm{CO}_{2}\right) \text { it }=\beta 0+\beta 1 \text { GDPit }+\beta 2 \text { ENRGY_CONSCit }+\beta 1 \mathrm{CAP} \_ \text {FORMit }+\beta 1 \text { POPit }+ \text { uit }
$$

Nevertheless, the study variables were altered to take into consideration the natural logarithm for estimation. Hence, obtaining elasticity interpretation besides the growth rate in GDP. The analysis was carried out using Eviews 9.5 software.

\section{Results}

\subsection{Descriptive Statistics}

The obtained values for $\mathrm{CO}_{2}$ emissions range between 212.69 to 10249463 with a positive skewness that is greater than 0 (normal distribution for skewness stands at 0 ). This suggests that the distribution has a long right tail. Likewise, the $\mathrm{CO}_{2}$ Kurtosis value is 41.3 and is greater than 3 (normal distribution for kurtosis stands at 3 ). This suggests that the distribution is peaked. However, Table 5 revealed that the data is not distributed normally as the $\mathrm{CO}_{2} P$-value, which stands at 0 is less than the significant levels of $1 \%, 5 \%$ and $10 \%$ proposed for the study. Hence, we reject the null hypothesis (H0).

The GDP values as revealed in Table 5 range between $-33.10 \%$ and $54.16 \%$ with a 0.86 skewness value. This indicates that GDP is slightly right-tailed. Also, it has a kurtosis value of 22.80 . This further suggests that it is peaked. Besides this, with a probability of 0 , the Jarque-Bera value remains high. Hence, the null hypothesis ( $\mathrm{H} 0$ ) is rejected using a significance level of $1 \%, 5 \%$ and $10 \%$.

Table 5 reveals that the value of energy consumption ranges between 125.79 and 8441.2 with a 1.15 skewness value. This indicates that energy consumption is right-tailed. Also, it has a kurtosis value of 3.6. This further suggests that it is peaked. Besides this, with a probability of 0 , the Jarque-Bera value remains high. Hence, the null hypothesis $(\mathrm{H} 0)$ is rejected using a significance level of $1 \%, 5 \%$ and $10 \%$. 
Table 5. Synopsis of descriptive statistics.

\begin{tabular}{|c|c|c|c|c|c|c|c|c|c|c|c|c|}
\hline Variables & Mean & Median & Maximum & Minimum & Std. Dev & Skewness & Kurtosis & Jarque-Bera & Probability & Sum & Sum Sq. Dev & Observations \\
\hline ENRGY_C & 2178.255 & 1474.045 & 8441.185 & 125.7875 & 1931.095 & 1.148612 & 3.589788 & 324.3803 & 0.000000 & $2,887,780$ & $4.77 \times 10^{9}$ & 1384 \\
\hline GDP & 4.011148 & 4.000000 & 54.15777 & -33.10084 & 4.600474 & 0.861933 & 22.79908 & $22,595.89$ & 0.000000 & 4683.724 & $21,033.41$ & 1373 \\
\hline $\mathrm{CO}_{2}$ & $351,706.8$ & $70,743.76$ & $10,249,463$ & 212.6860 & $991,655.0$ & 5.770660 & 41.29187 & $93,035.79$ & 0.000000 & $4.85 \times 10^{8}$ & $1.35 \times 10^{15}$ & 1396 \\
\hline CAP_FORM & $1.92 \times 10^{11}$ & $4.77 \times 10^{10}$ & $3.56 \times 10^{12}$ & $3.42 \times 10^{8}$ & $4.49 \times 10^{11}$ & 4.649739 & 27.03661 & $34,125.27$ & 0.000000 & $2.36 \times 10^{14}$ & $2.47 \times 10^{26}$ & 1233 \\
\hline POP & $79,996,313$ & $27,192,132$ & $1.36 \times 10^{9}$ & $514,877.0$ & $2.01 \times 10^{8}$ & 5.123719 & 29.44615 & $46,923.84$ & 0.000000 & $1.08 \times 10^{11}$ & $5.57 \times 10^{19}$ & 1400 \\
\hline
\end{tabular}


Also, Table 5 reveals that the values for capital formation range between $3.42 \mathrm{e}+08$ and $3.56 \mathrm{e}+12$ with a 4.95 skewness value. This means that capital formation is right-tailed. Also, it has a kurtosis value of 30.4 and a mean value that is greater than the median. This further suggests that it is peaked. Besides this, with a probability of 0 , the Jarque-Bera value remains high. Hence, the null hypothesis (H0) is rejected using a significance level of $1 \%, 5 \%$ and $10 \%$.

Furthermore, Table 5 reveals that the population values range between 514877 and $1.36 \mathrm{e}+09$ with a 5.12 skewness value. This means that the population is right-tailed. Also, it has a kurtosis value of 29.4 and a mean value that is greater than the median. This further suggests that it is peaked. Besides this, with a probability of 0 , the Jarque-Bera value remains high. Hence, the null hypothesis (H0) is rejected using a significance level of $1 \%, 5 \%$ and $10 \%$.

\subsection{Result of Correlation Analysis}

Table 6 reveals that there exists a positive relationship between the study variables and $\mathrm{CO}_{2}$. The highest value emerges from the capital formation (i.e., 0.89) having a positive and strong correlation, while GDP has the lowest value (i.e., 0.07) having a positive but weak correlation. Also, revealed in the table are different relationship types that exist between the study variables.

Table 6. Result of correlation matrix.

\begin{tabular}{cccccc}
\hline Variables & ENRGY_C & GDP & CO $_{2}$ & CAP_FORM & POP \\
\hline ENRGY_C & 1.000000 & -0.258039 & 0.266449 & 0.395075 & -0.121009 \\
\hline GDP & -0.258030 & 1.000000 & 0.067149 & -0.040234 & 0.194128 \\
\hline CO $_{2}$ & 0.266449 & 0.067149 & 1.000000 & 0.889258 & 0.675107 \\
\hline CAP_FORM & 0.395075 & -0.040234 & 0.889258 & 1.000000 & 0.454021 \\
\hline POP & -0.121009 & 0.194128 & 0.675107 & 0.454021 & 1.000000 \\
\hline
\end{tabular}

\subsection{Multicollinearity Test}

Table 7 shows that all the study variables have a correlation coefficient that is less than 1 . This means that there exists no high correlation between the study variables. Hence, the absence of multicollinearity.

Table 7. Independent variables correlation coefficient.

\begin{tabular}{ccccc}
\hline Variables & ENRGY_C & GDP & CAP_FORM & POP \\
\hline ENRGY_C & 1.000000 & -0.258030 & 0.395057 & -0.121009 \\
\hline GDP & -0.258030 & 1.000000 & -0.040234 & 0.194128 \\
\hline CAP_FORM & 0.395075 & -0.040234 & 1.000000 & 0.454021 \\
\hline POP & -0.121009 & 0.194128 & 0.454021 & 1.000000 \\
\hline
\end{tabular}

\subsection{Unit Root Test}

Table 8 presents the study variables unit root test outcomes at the level and first difference. H0 is identified as the unit root and it is perceived as non-stationary, while $\mathrm{H} 1$ is termed stationarity. The table reveals that capital formation, energy consumption, population and $\mathrm{CO}_{2}$ emissions are stationary at I (1). However, GDP is stationary at I (0).

Using a 5\% significance level at both level and first difference, the result reveals that the null hypothesis is accepted at level (for IPS), while it is rejected at the first difference for both (LLC and IPS). This is because the significance level at $5 \%(0.05)$ at first difference is greater than the $P$-value of 0.00 ; hence, at I (1), $\mathrm{LCO}_{2}$ is classified as a stationary variable. Also, using a significance level of 5\% (0.05), 
the null hypothesis is rejected because the significance level is greater than the $P$-value of 0.00 . At I (0), LGDP is termed a stationary variable.

Table 8. At level unit root test- $\mathrm{CO}_{2}$.

\begin{tabular}{clccccc}
\hline Method & Stage & LENRGY_CONSCLGDP & LCO $_{2}$ & LCAP_FORM & LPOP \\
\hline IPS & Level & 0.8871 & 0.0000 & 0.9999 & 0.9992 & 0.9737 \\
\hline LLC & Level & 0.0284 & 0.0000 & 0.0033 & 0.0017 & 0.0000 \\
\hline IPS & 1st Difference & 0.0000 & 0.0000 & 0.0000 & 0.0000 & 0.0001 \\
\hline LLC & 1st Difference & 0.0000 & 0.0000 & 0.0000 & 0.0000 & 0.0219 \\
\hline
\end{tabular}

IPS = Im, Pesaran and Shin W-stat, and LLC = Levin, Lin and Chu.

Table 8 presents the unit root tests at the level and first difference. Using a 5\% (0.05) significance level at both level and first difference, the result reveals that the null hypothesis is accepted at level (for IPS), while it is rejected at the first difference for both (LLC and IPS). This is because the significance level is greater than the $P$-value of 0.00 ; hence, at I (1), LENERGY_CONSC is classified as a stationary variable.

Likewise, using a significance level of 5\% (0.05), Table 8 reveals that at I (0), LCAP_FORM is not stationary for IPS. However, at I (1), it is stationary for both unit root tests. This is because the significance level is greater than the $P$-value of 0 .

At I (0), LPOP is not stationary for IPS using a 5\% significance level as shown in Table 8. However, at I (1), it is stationary for both unit root tests. This is because the significance level is greater than the $P$-value of 0 . Hence, the null hypothesis is rejected.

\subsection{Cointegration Test}

Cointegration establishes the long-run relationship between two or more study variables. Hence, some pairs of variables that are not identical could move together. The alternative hypothesis is cointegration, while the null hypothesis is no cointegration based on the results from the Pedroni and Kao cointegration test as shown in Table 9. Most of the variables indicate that the null hypothesis should be rejected, thus, there exists a long-run relationship among the study variables. Hence, they are cointegrated. This is supported by the findings of Esso and Keho (Esso 2016).

\subsection{Granger Causality Tests}

Given that a long-run relationship exists between the study variables based on the cointegration test results, a further test was carried out using the Granger causality test. The Granger causality test focuses on examining and assessing if any causal relationship exists among the study variables as shown in Table 10. The study outcome is in line with Yang and Zhao (2017) findings.

\subsection{Regression Analysis}

All the study variables are positively significant at significance levels of $1 \%, 5 \%$ and $10 \%$ significance. This is because all the study variables' $P$-values are lesser than $0.01,0.05$ and 0.10 , respectively. Hence, on average, holding the other variables constant, an increase in GDP will result in an increase in $\mathrm{CO}_{2}$ emissions by $1.02 \%$. Also, an increase in energy consumption by $1 \%$ will result in a $0.88 \%$ increase in $\mathrm{CO}_{2}$ emissions. Likewise, a rise in capital stock by $1 \%$ will give rise to a $0.29 \%$ increase in $\mathrm{CO}_{2}$ emissions, while a $1 \%$ increase in population will give rise to a $0.78 \%$ increase in $\mathrm{CO}_{2}$ emissions as shown in Table 11. 
Table 9. Synopsis of Cointegration Tests.

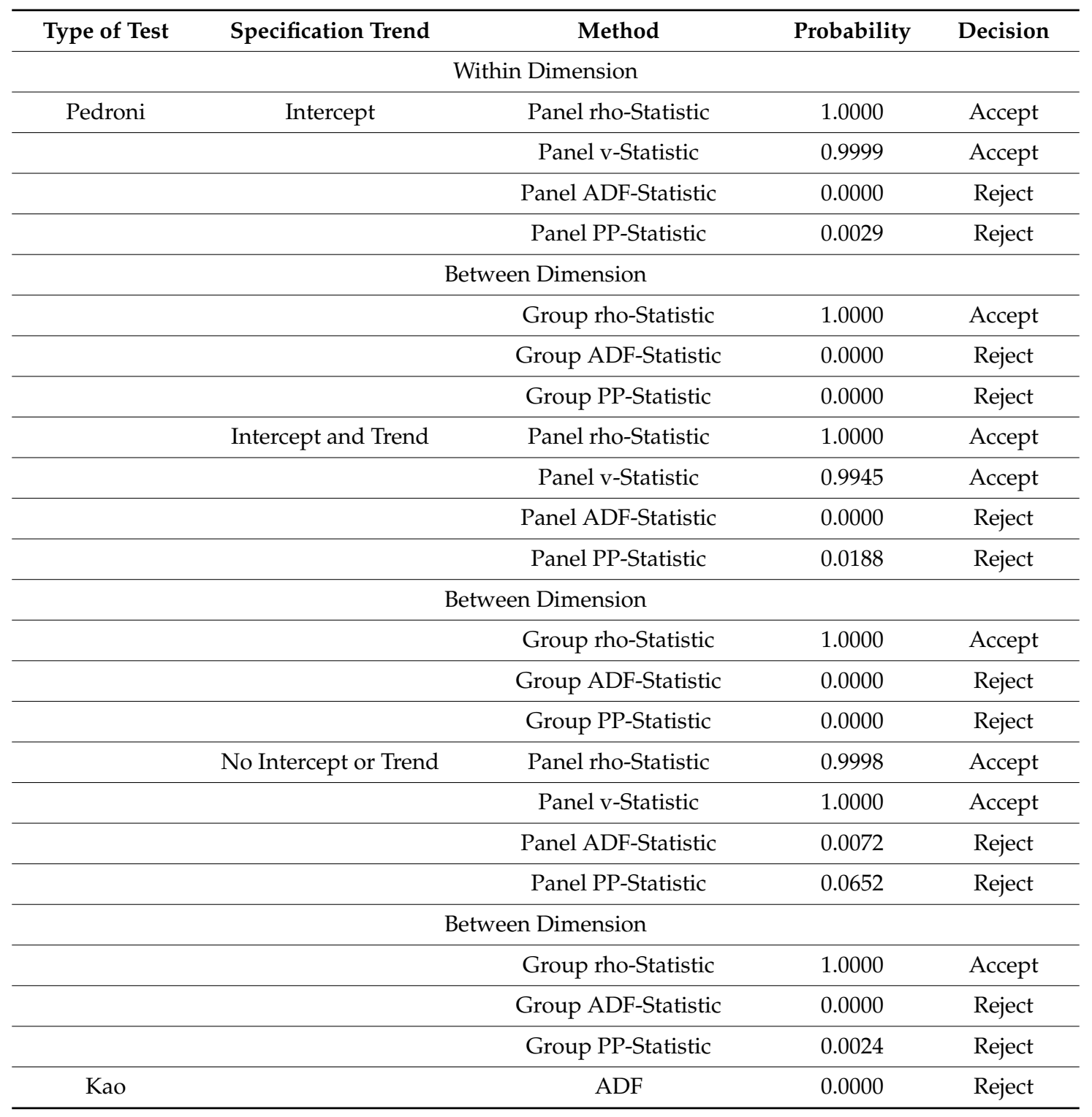

Furthermore, Table 11 revealed a 91\% R-squared with little or slight difference to the adjusted $\mathrm{R}$-squared of $91 \%$. This shows how the variance in the dependent variables can be explained using the independent variables. Hence, most of the $\mathrm{CO}_{2}$ emission (i.e., $91 \%$ ) is explained by the study independent variables. Further assessment of the independent variables' total performance (i.e., a test of overall significance) was carried out using the F-statistic to test if all the study independent variables coefficient is equal to zero.

$$
\mathrm{H} 0=\beta 1=0, \beta 2=0, \beta 3=0, \beta 4=0
$$

$\mathrm{H} 1=$ At least one of $\beta 4 \neq 0$.

At a significance level of $5 \%$, the null hypothesis is rejected because at least one of the coefficients $\beta n$, is not equal to zero. 
Table 10. Synopsis of Granger causality test.

\begin{tabular}{|c|c|c|c|}
\hline Hypothesis & Observation & Probability & F-Statistic \\
\hline $\begin{array}{c}\text { LC02 does not Granger Cause LGDP and } \\
\text { vice versa }\end{array}$ & 955 & $\begin{array}{l}7 \times 10^{-5} \\
2 \times 10^{-5}\end{array}$ & $\begin{array}{l}9.67521 \\
10.8376\end{array}$ \\
\hline $\begin{array}{l}\text { LC02 does not Granger Cause } \\
\text { LCAP_FORM and vice versa }\end{array}$ & 1102 & $\begin{array}{c}2 \times 10^{-5} \\
0.0267\end{array}$ & $\begin{array}{l}10.9395 \\
3.63390\end{array}$ \\
\hline $\begin{array}{l}\text { LC02 does not Granger Cause } \\
\text { LENERGY_CONSC and vice versa }\end{array}$ & 1240 & $\begin{array}{c}0.1353 \\
7 \times 10^{-11}\end{array}$ & $\begin{array}{l}2.00341 \\
23.7898\end{array}$ \\
\hline $\begin{array}{l}\text { LC02 does not Granger Cause LPOP and } \\
\text { vice versa }\end{array}$ & 1256 & $\begin{array}{c}0.0008 \\
5 \times 10^{-9}\end{array}$ & $\begin{array}{l}7.21191 \\
19.3766\end{array}$ \\
\hline $\begin{array}{l}\text { LGDP does not Granger Cause } \\
\text { LCAP_FORM and vice versa }\end{array}$ & 851 & $\begin{array}{l}4 \times 10^{-6} \\
4 \times 10^{-7}\end{array}$ & $\begin{array}{l}12.4948 \\
15.0342\end{array}$ \\
\hline $\begin{array}{l}\text { LGDP does not Granger Cause } \\
\text { LENERGY_CONSC and vice versa }\end{array}$ & 939 & $\begin{array}{c}0.1947 \\
6 \times 10^{-12}\end{array}$ & $\begin{array}{l}1.63895 \\
26.6460\end{array}$ \\
\hline $\begin{array}{l}\text { LENERGY_CONSC does not Granger } \\
\text { Cause LCAP_FORM and vice versa }\end{array}$ & 1092 & $\begin{array}{l}0.1403 \\
0.0329\end{array}$ & $\begin{array}{l}1.96732 \\
3.42512\end{array}$ \\
\hline $\begin{array}{c}\text { LGDP does not Granger Cause LPOP and } \\
\text { vice versa }\end{array}$ & 955 & $\begin{array}{l}0.0672 \\
0.0106\end{array}$ & $\begin{array}{l}2.70768 \\
4.56586\end{array}$ \\
\hline $\begin{array}{l}\text { LCAP_FORM does not Granger Cause } \\
\text { LPOP and vice versa }\end{array}$ & 1102 & $\begin{array}{c}0.1852 \\
2 \times 10^{-5}\end{array}$ & $\begin{array}{l}1.68911 \\
11.1630\end{array}$ \\
\hline $\begin{array}{l}\text { LENERGY_CONSC does not Granger } \\
\text { Cause LPOP and vice versa }\end{array}$ & 1244 & $\begin{array}{l}0.0135 \\
0.6512\end{array}$ & $\begin{array}{l}4.31957 \\
0.42915\end{array}$ \\
\hline
\end{tabular}

Table 11. Result of pooled OLS.

\begin{tabular}{ccccc}
\hline Variables & Std. Error & Coefficient & Probability & T-Statistic \\
\hline LENRGY_CONSC & 0.035143 & 1.888638 & 0.0000 & 25.28638 \\
\hline GDP & 0.004007 & 0.010245 & 0.0107 & 2.557112 \\
\hline CO $_{2}$ & 0.257124 & -15.75982 & 0.0000 & -61.29278 \\
\hline LPOP & 0.023221 & 1.778584 & 0.0000 & 33.52908 \\
\hline LCAP_FORM & 0.022093 & 0.292241 & 0.0000 & 13.22807 \\
\hline \multicolumn{5}{c}{ Adjusted R-squared 0.909866 } \\
\hline \multicolumn{5}{c}{ F-Statistic 3082.384 } \\
\hline
\end{tabular}

\subsection{Fixed Effects}

The unobserved heterogeneity is accounted for by using this method to estimate the mean deviations to eliminate heterogeneity. Based on the results as shown in Table 12 we have rewritten the econometric model as:

$$
1 \mathrm{CO}_{2}=-16.33+0.002 \mathrm{gdp}+1.09 \text { lenergy_consc }+0.05 \text { lcap_form }+1.081 \mathrm{pop}+\mathrm{vit}
$$

Table 12 shows further that at 1\%, 5\% and 10\% significance levels, all the study variables are still positively significant except for GDP, which is only significant at $10 \%$. However, on average, holding the other variables constant, an increase in the GDP growth rate will result in an increase in $\mathrm{CO}_{2}$ emissions by $0.15 \%$. Also, an increase in energy consumption by $1 \%$ will result in a $1.09 \%$ increase in $\mathrm{CO}_{2}$ emissions. Likewise, an increase in both the population and capital stock by $1 \%$ will give rise to a $1.08 \%$ and $0.05 \%$ increase in $\mathrm{CO}_{2}$ emissions, respectively. Based on the fixed effects method, a $100 \%$ $\mathrm{R}$-squared was obtained. This suggests a rise in the independent variables explanatory power. Also, 
F-statistic reveals that the rejection of the null hypothesis as at a $P$-value of 0.00 is lower than the $5 \%$ significance level. This further suggests that at least one of the coefficients $\beta \mathrm{n}$ is different from zero.

Table 12. Result of fixed effect estimation.

\begin{tabular}{ccccc}
\hline Variables & Std. Error & Coefficient & Probability & T-Statistic \\
\hline LENRGY_CONSC & 0.030737 & 1.088263 & 0.0000 & 35.40530 \\
\hline GDP & 0.000816 & 0.001593 & 0.0511 & 1.952462 \\
\hline CO $_{2}$ & 0.689571 & -16.32856 & 0.0000 & -23.67930 \\
\hline LPOP & 0.048312 & 1.076580 & 0.0000 & 22.28392 \\
\hline LCAP_FORM & 0.011687 & 0.047629 & 0.0000 & 4.075240 \\
\hline \multicolumn{5}{c}{ Adjusted R-squared 0.997087 } \\
\hline \multicolumn{5}{c}{ F-Statistic 5971.530 } \\
\hline
\end{tabular}

\subsection{Interaction of Variables}

This approach explains a situation where two independent variables have a joint effect. Hence, these two variables are said to have an influence on one another. The impact level of a variable relies on the level of the other variable. Energy consumption and population are identified to interact in this study. This means that energy consumption, as a variable, depends on the population. Likewise, the effect of the population depends on those that consume energy. Based on the results as shown in Table 13, we have rewritten the econometric model as:

$$
\begin{gathered}
1 \mathrm{CO}_{2}=-11.87+0.01 \mathrm{gdp}+0.34 \text { lenergy_consc }+0.30 \text { lcap_form }+0.551 \mathrm{pop} \\
+0.03 \text { lenrgy_consc }{ }^{*} \text { lpop }+ \text { vit }
\end{gathered}
$$

Table 13. Result of pooled OLS with interaction.

\begin{tabular}{ccccc}
\hline Variables & Std. Error & Coefficient & Probability & T-Statistic \\
\hline LENRGY_CONSC & 0.215666 & 0.344621 & 0.1103 & 1.597936 \\
\hline GDP & 0.003998 & 0.010177 & 0.0110 & 2.545725 \\
\hline CO $_{2}$ & 1.544142 & -11.86706 & 0.0000 & -7.685213 \\
\hline LPOP & 0.092002 & 0.550960 & 0.0000 & 5.988572 \\
\hline LCAP_FORM & 0.022104 & 0.296451 & 0.0000 & 13.41173 \\
\hline LENRGY_CONSC*LPOP & 0.012145 & 0.031048 & 0.0107 \\
\hline \multicolumn{5}{c}{ R-squared 0.910642 } \\
\hline \multicolumn{5}{c}{ F-Statistic 2478.431 } \\
\hline
\end{tabular}

The results reveal that there exists a positively significant relationship between the study variables and $\mathrm{CO}_{2}$ emissions except for energy consumption. This is because it has a $P$-value of 0.11 , which is insignificant even though it is positive. This is greater than the significance levels of $1 \%, 5 \%$ or $10 \%$. However, on average, holding the other variables constant, a $1 \%$ increase in population will give rise to a $0.55 \%$ increase in $\mathrm{CO}_{2}$ emissions. Likewise, an increase in capital stock by $1 \%$ will give rise to a $0.30 \%$ increase in $\mathrm{CO}_{2}$ emissions, while an increase in GDP will result in an increase in $\mathrm{CO}_{2}$ emissions by $1.02 \%$. Considering the level of significance between energy consumption and the population, an increase, in interactive terms, of energy consumption and population by $1 \%$ will result 
in a $0.03 \%$ increase in $\mathrm{CO}_{2}$ emissions. This suggests that the $\mathrm{CO}_{2}$ emissions level, as it relates to energy consumption, changes depending on the value of the population.

Furthermore, Table 13 revealed a relatively high R-squared of $91 \%$. This suggests that $\mathrm{CO}_{2}$ emission levels are explained by the independent variables and the F-statistic. Hence, the null hypothesis is rejected. This indicates that at least one of the coefficients of $\beta n$, is different from zero. As a result, $\mathrm{CO}_{2}$ emissions are jointly influenced by the independent variables.

\section{Conclusions and Discussion}

This study explored the effect of energy consumption and economic growth on $\mathrm{CO}_{2}$ emission levels by evaluating data from 70 countries between the period of 1994 and 2013. Hence, it draws attention to the fact that human activities over the years due to urbanization, industrialization and growth in population have been a major contributor to the global increase in $\mathrm{CO}_{2}$ emission levels. This poses a major risk to human well-being and the environment at large.

Findings obtained from using the Pesaran, Levin, Lin and Chu (LLC) and the Im and Shin W-stat (IPS) unit root tests revealed that all the study variables were stationary at I (1) except for GDP. Also, it was revealed that a long-run relationship exists among the study variables using Pedroni and Kao cointegration tests. This aligns with the study outcomes of Nain et al. [33], which found that there exists a long-run relationship between the three variables. However, their study observed that there is no feedback causation in the short and long run at both aggregated and disaggregated levels. This is contrary to the current study's findings that found that a bi-directional causal relationship exists between the study variables and $\mathrm{CO}_{2}$ emissions using the Granger causality tests, except for energy consumption, which has a unidirectional causal relationship.

Likewise, the results from using the pooled OLS revealed that all the study variables are positively significant. This indicates that all the study variables contribute to $\mathrm{CO}_{2}$ emission levels. In addition, using the fixed-effect method revealed that all the study variables are positively significant except for economic growth which is only significant at a $10 \%$ significance level. This aligns with Dritsaki and Dritsaki [36] study results, which found that there exist a significant and positive relationships between the variables under consideration. The results of the R-squared for both the fixed effects and pooled OLS models, which are $100 \%$ and $91 \%$, respectively, suggest that the study independent variables (i.e., energy consumption, GDP, population and capital stock) explain the variance in the $\mathrm{CO}_{2}$ emission levels, which is the dependent variable. This means that the models are a good fit. Another key finding of the study is the introduction of an interaction term between the study variables (i.e., energy consumption and population) to the pooled OLS. The results revealed that there exists a positively significant interaction at $5 \%$ and $10 \%$ significance levels. This means that there exists a joint effect among the variables and that both variables should be kept in the model.

\section{Policy Implications and Future Research}

The study concludes that there exists a relationship between the three variables, as energy consumption and economic growth impact $\mathrm{CO}_{2}$ emissions. As a result, policymakers should pay attention to making energy and economic related policies that focus on improving energy efficiency and promoting economic growth with no contributing impact on $\mathrm{CO}_{2}$ emission. Also, the implementation of such policies should be done without affecting the energy consumption and economic growth of the society. For instance, climate finance has been taken on board at the global level as one of the actions needed to address the environmental impacts of $\mathrm{CO}_{2}$ emissions. This involves investing in clean and climate-friendly options that will foster economic growth. The renewable energy sector fits into such an initiative. Future studies should therefore focus on creating awareness and promoting investment in different renewable energy sources. This will avail both developed and emerging economies of clean energy sources for both commercial and personal consumption. Hence, reducing any damage to the environment or limiting economic growth of nations. 
Moreover, measures to curb deforestation by the citizens of the countries should be strengthened, since these activities release $\mathrm{CO}_{2}$ emissions into the atmosphere. Emission standards should be set for industries and emission monitoring strategies should be put in place to ensure compliance. The development of the financial markets in these countries can also assist in enhancing investment in research and development in modern energy-efficient technologies, thus ensuring lower emissions. Further, since $\mathrm{CO}_{2}$ is not a local pollutant but a global one, perhaps international cooperation would also help to reduce its emissions. Creating a union between these countries to establish unified environmental acts will increase the effectiveness of such regulations on the pollution levels. This does not however rule out individual national environmental laws and regulations. A lack of application of relevant laws and regulations will result in adverse effects on economic growth.

It is however important to state that the major limitation of this study was the unavailability of data for the variables considered for some of the countries used for the study. This also placed a limit in the choice of time horizon for the study (i.e., 1994-2013) as the authors would have preferred to extend the study time horizon to a much more up to date year (i.e., 2018).

Author Contributions: Conceptualization O.A.O. and M.A.O.; Investigation, M.A.O.; Methodology, O.A.O. and A.O. (Afolabi Otitoju); Validation, M.A.O.; Visualization, A.O. (Adekunle Oke); Writing—original draft, O.A.O.; Writing-review \& editing, A.O. (Afolabi Otitoju) and A.O. (Adekunle Oke). All authors have read and agreed to the published version of the manuscript.

Funding: This research received no external funding.

Conflicts of Interest: The authors declare no conflict of interest.

\section{References}

1. Balint, T.; Lamperti, F.; Mandel, A.; Napoletano, M.; Roventini, A.; Sapio, A. Complexity and the economics of climate change: A survey and a look forward. Ecol. Econ. 2017, 138, 252-265. [CrossRef]

2. Fouquet, R. Lessons from energy history for climate policy: Technological change, demand and economic development. Energy Res. Soc. Sci. 2016, 22, 79-93. [CrossRef]

3. Urry, J. Climate change and society. In Why the Social Sciences Matter; Palgrave Macmillan: London, UK, 2015; pp. 45-59.

4. Zhang, C.; Zhou, K.; Yang, S.; Shao, Z. On electricity consumption and economic growth in China. Renew. Sustain. Energy Rev. 2017, 76, 353-368. [CrossRef]

5. Yildirim, H.H. Economic Growth and Energy Consumption for OECD Countries. In Regional Studies on Economic Growth, Financial Economics and Management; Springer: Cham, Switzerland, 2017; pp. 245-255. [CrossRef]

6. Phimphanthavong, H. The impacts of economic growth on environmental conditions in Laos. Int. J. Bus. Manag. Econ. Res. 2013, 4, 766-774.

7. Kasman, A.; Duman, Y.S. $\mathrm{CO}_{2}$ emissions, economic growth, energy consumption, trade and urbanization in new EU member and candidate countries: A panel data analysis. Econ. Model. 2015, 44, 97-103. [CrossRef]

8. Bushell, S.; Buisson, G.S.; Workman, M.; Colley, T. Strategic narratives in climate change: Towards a unifying narrative to address the action gap on climate change. Energy Res. Soc. Sci. 2017, 28, 39-49. [CrossRef]

9. Talbi, B. $\mathrm{CO}_{2}$ emissions reduction in road transport sector in Tunisia. Renew. Sustain. Energy Rev. 2017, 69, 232-238. [CrossRef]

10. Wang, A.; Lin, B. Assessing $\mathrm{CO}_{2}$ emissions in China's commercial sector: Determinants and reduction strategies. J. Clean. Prod. 2017, 164, 1542-1552. [CrossRef]

11. Hossain, $\mathrm{S}$. An econometric analysis for $\mathrm{CO}_{2}$ emissions, energy consumption, economic growth, foreign trade and urbanization of Japan. Low Carbon Econ. 2012, 3. [CrossRef]

12. Paiva, S.L.; Savi, M.A.; Viola, F.M.; Leiroz, A.J. Global warming description using Daisyworld model with greenhouse gases. Biosystems 2014, 125, 1-15. [CrossRef]

13. Resnik, D.B. Climate change: Causes, consequences, policy, and ethics. In Bioethical Insights into Values and Policy; Springer: Cham, Switzerland, 2016; pp. 47-58.

14. Meltzer, J.P. Financing low carbon, climate resilient infrastructure: The role of climate finance and green financial systems. Clim. Resilient Infrastruct. Role Clim. Financ. Green Financ. Syst. 2016. [CrossRef] 
15. Ozturk, I.; Acaravci, A. $\mathrm{CO}_{2}$ emissions, energy consumption and economic growth in Turkey. Renew. Sustain. Energy Rev. 2010, 14, 3220-3225. [CrossRef]

16. Wang, S.S.; Zhou, D.Q.; Zhou, P.; Wang, Q.W. $\mathrm{CO}_{2}$ emissions, energy consumption and economic growth in China: A panel data analysis. Energy Policy 2011, 39, 4870-4875. [CrossRef]

17. Esso, L.J.; Keho, Y. Energy consumption, economic growth and carbon emissions: Cointegration and causality evidence from selected African countries. Energy 2016, 114, 492-497. [CrossRef]

18. Rahman, M.M. Do population density, economic growth, energy use and exports adversely affect environmental quality in Asian populous countries? Renew. Sustain. Energy Rev. 2017, 77, 506-514. [CrossRef]

19. Amri, F. Intercourse across economic growth, trade and renewable energy consumption in developing and developed countries. Renew. Sustain. Energy Rev. 2017, 69, 527-534. [CrossRef]

20. Saidi, K.; Hammami, S. The impact of $\mathrm{CO}_{2}$ emissions and economic growth on energy consumption in 58 countries. Energy Rep. 2015, 1, 62-70. [CrossRef]

21. Dogan, E.; Seker, F. An investigation on the determinants of carbon emissions for OECD countries: Empirical evidence from panel models robust to heterogeneity and cross-sectional dependence. Environ. Sci. Pollut. Res. 2016, 23, 14646-14655. [CrossRef]

22. Karmellos, M.; Kopidou, D.; Diakoulaki, D. A decomposition analysis of the driving factors of $\mathrm{CO}_{2}$ (Carbon dioxide) emissions from the power sector in the European Union countries. Energy 2016, 94, 680-692. [CrossRef]

23. Stolyarova, E. Carbon Dioxide Emissions, Economic Growth and Energy Mix: Empirical Evidence From 93 Countries; Climate Economics Chair Paris-Dauphine University: Paris, France, 2009; Available online: https://ecomod.net/system/files/CO2_Growth_Energy_Mix.pdf (accessed on 1 September 2020).

24. Sharma, S.S. Determinants of carbon dioxide emissions: Empirical evidence from 69 countries. Appl. Energy 2011, 88, 376-382. [CrossRef]

25. Cetin, M.; Ecevit, E. Urbanization, Energy Consumption and $\mathrm{CO}_{2}$ Emissions in Sub-Saharan Countries: A Panel Cointegration and Causality Analysis. J. Econ. Dev. Stud. 2015, 3, 66-76. [CrossRef]

26. Keho, Y. What drives energy consumption in developing countries? The experience of selected African countries. Energy Policy 2016, 91, 233-246. [CrossRef]

27. Zakarya, G.Y.; Mostefa, B.; Abbes, S.M.; Seghir, G.M. Factors Affecting $\mathrm{CO}_{2}$ Emissions in the BRICS countries: A panel data analysis. Procedia Econ. Financ. 2015, 26, 114-125. [CrossRef]

28. Ab-Rahim, R.; Xin-Di, T. The determinants of $\mathrm{CO}_{2}$ emissions in ASEAN 3 countries. J. Entrep. Bus. 2016, 4, 26-37. [CrossRef]

29. Jiang, X.; Guan, D. Determinants of global $\mathrm{CO}_{2}$ emissions growth. Appl. Energy 2016, 184, $1132-1141$. [CrossRef]

30. Jiang, S.; Yang, C.; Guo, J.; Ding, Z.; Tian, L.; Zhang, J. Uncovering the Driving Factors of Carbon Emissions in an Investment Allocation Model of China's High-Carbon and Low-Carbon Energy. Sustainability 2017, 9 , 1021. [CrossRef]

31. Abdallh, A.A.; Abugamos, H. A semi-parametric panel data analysis on the urbanisation-carbon emissions nexus for the MENA countries. Renew. Sustain. Energy Rev. 2017, 78, 1350-1356. [CrossRef]

32. Mirza, F.M.; Kanwal, A. Energy consumption, carbon emissions and economic growth in Pakistan: Dynamic causality analysis. Renew. Sustain. Energy Rev. 2017, 72, 1233-1240. [CrossRef]

33. Nain, M.Z.; Ahmad, W.; Kamaiah, B. Economic growth, energy consumption and CO2 emissions in India: A disaggregated causal analysis. Int. J. Sustain. Energy 2017, 36, 807-824. [CrossRef]

34. Rehman, M.U.; Rashid, M. Energy consumption to environmental degradation, the growth appetite in SAARC nations. Renew. Energy 2017, 111, 284-294. [CrossRef]

35. Dogan, E.; Aslan, A. Exploring the relationship among $\mathrm{CO}_{2}$ emissions, real GDP, energy consumption and tourism in the EU and candidate countries: Evidence from panel models robust to heterogeneity and cross-sectional dependence. Renew. Sustain. Energy Rev. 2017, 77, 239-245. [CrossRef]

36. Dritsaki, C.; Dritsaki, M. Causal relationship between energy consumption, economic growth and $\mathrm{CO}_{2}$ emissions: A dynamic panel data approach. Int. J. Energy Econ. Policy 2014, 4, 125.

37. Hwang, J.; Yoo, S. Energy consumption, $\mathrm{CO}_{2}$ emissions, and economic growth: Evidence from Indonesia. Qual. Quant. 2014, 48, 63-73. [CrossRef] 
38. Omri, A. $\mathrm{CO}_{2}$ emissions, energy consumption and economic growth nexus in MENA countries: Evidence from simultaneous equations models. Energy Econ. 2013, 40, 657-664. [CrossRef]

39. Alam, M.J.; Begum, I.A.; Buysse, J.; Rahman, S.; Van Huylenbroeck, G. Dynamic modeling of causal relationship between energy consumption, $\mathrm{CO}_{2}$ emissions and economic growth in India. Renew. Sustain. Energy Rev. 2011, 15, 3243-3251. [CrossRef]

40. Hossain, M.S. Panel estimation for $\mathrm{CO}_{2}$ emissions, energy consumption, economic growth, trade openness and urbanization of newly industrialized countries. Energy Policy 2011, 39, 6991-6999. [CrossRef]

41. Menyah, K.; Wolde-Rufael, Y. Energy consumption, pollutant emissions and economic growth in South Africa. Energy Econ. 2010, 32, 1374-1382. [CrossRef]

42. Pablo-Romero, M.D.; De Jesús, J. Economic growth and energy consumption: The energy-environmental Kuznets curve for Latin America and the Caribbean. Renew. Sustain. Energy Rev. 2016, 60, 1343-1350. [CrossRef]

43. Granoff, I.; Hogarth, J.R.; Miller, A. Nested barriers to low-carbon infrastructure investment. Nat. Clim. Chang. 2016, 6, 1065-1071. [CrossRef]

44. World Bank. Climate Finance: Innovative Approaches in Supporting the Climate Action. Open Learn. Course. 2017. Available online: http://www.worldbank.org (accessed on 24 March 2020).

45. Ellis, E.C.; Kaplan, J.O.; Fuller, D.Q.; Vavrus, S.; Goldewijk, K.K.; Verburg, P.H. Used planet: A global history. Proc. Natl. Acad. Sci. USA 2013, 110, 7978-7985. [CrossRef]

46. Steckel, J.C.; Jakob, M.; Flachsland, C.; Kornek, U.; Lessmann, K.; Edenhofer, O. From climate finance toward sustainable development finance. Wiley Interdiscip. Rev. Clim. Chang. 2017, 8. [CrossRef]

47. Shakouri, B.; Khoshnevis Yazdi, S. Causality between renewable energy, energy consumption, and economic growth. Energy Sources Part B Econ. Plan. Policy 2017, 1-8. [CrossRef]

48. Creswell, J. Research Design: Qualitative, Quantitative, and Mixed Methods Approaches; SAGE Publications, Incorporated: Los Angeles, CA, USA, 2014.

49. O'Leary, Z. The Essential Guide to Doing Your Research Project; SAGE Publications, Incorporated: Los Angeles, CA, USA, 2017.

50. Knight, K.W.; Schor, J.B. Economic growth and climate change: A cross-national analysis of territorial and consumption-based carbon emissions in high-income countries. Sustainability 2014, 6, 3722-3731. [CrossRef]

51. Zhang, C.; Tan, Z. The relationships between population factors and China's carbon emissions: Does population aging matter? Renew. Sustain. Energy Rev. 2016, 65, 1018-1025. [CrossRef]

52. Wilson, J. Essentials of Business Research: A Guide to Doing Your Research Project; SAGE Publications, Incorporated: Los Angeles, CA, USA, 2010. 